\title{
SOIL ENZYMES AS BIOINDICATORS OF SOIL ECOSYSTEM STATUS
}

\author{
UTOBO, E.B. ${ }^{1} *-$ TEWARI, $^{2}{ }^{2}$ \\ ${ }^{1}$ Department of Environmental Science, G.B. Pant Uni. of Agric. and Tech., \\ Pantnagar, US Negar, Uttarankhand, 263145, India. \\ (Phone: +91-9045313022) \\ ${ }^{2}$ Department of Microbiology, G.B. Pant Uni. of Agric. and Tech., \\ Pantnagar, US Negar, Uttarankhand, 263145, India. \\ (Phone: +91-9412120605) \\ *Corresponding author \\ e-mail:emekabenjamin@yahoo.co.uk \\ (Received $17^{\text {th }}$ Oct 2013; accepted $14^{\text {th }}$ Aug 2014)
}

\begin{abstract}
A variety of methods were developed to measure soil biological activity. All these methods are not suited to produce generally accepted results, but they give relative information about the ecological status of soil. Soil enzymatic activity assays is only one way to measure the ecosystem status of soils. The technique is quite simple and produces reproducible results, and is nowadays of practical importance because the influence of agro-chemicals, industrial waste, heavy metals, as well as soil fertility management can be measured. Especially the search for urease inhibitor is of particular interest in order to reduce ammonia losses from soils. Soil enzymes have been reported as useful soil quality indicators due to their relationship to soil biology, being operationally practical, sensitive, integrative, ease to measure and described as "biological fingerprints" of past soil management, and relate to soil tillage and structure. The focus of this article is to provide a review of soil enzyme activity as a biological, process-level indicator for impacts of natural and anthropogenic activities on soils. This knowledge of soil enzymology can be applicable as bioindicator to human endeavour of ecosystem perturbation, agricultural practices and xenobiotic pollution.
\end{abstract}

Keywords: soil fertility management, ecosystem perturbation, agricultural practices, xenobiotics

\section{Introduction}

Soil is a living-dynamic, non-renewable resource and its conditions influence food production, environmental efficiency and global balance (Dick, 1997; Doran and Zeiss, 2000). The quality of soil depends in part on its natural composition, and also on the changes caused by human use and management (Pierce and Larson, 1993). Human factors influencing the environment of the soil can be divided into two categories: those resulting in soil pollution and those devoted to improve the productivity of soil (Gianfreda and Bollag, 1996). A soil is biologically active, when biological processes proceed rapidly, i.e. in a distinct span of time a lot of metabolites are produced (Schaller, 2009). A variety of methods were developed to measure soil biological activity. All these methods are not suited to produce generally accepted results, but they give relative information about the ecological status of soil ecosystem (Burns, 1982; Frankenberger and Dick, 1983). The soil enzymatic activity assay is only one way to measure the ecosystem status of soils. Baldrian (2009) proposed a variety of methods for measuring enzymatic activities in soils. These techniques are quite simple and produce reproducible results, but they often differ in the mode of detection (spectrophotometry, fluorescence, radiolabelling), the reaction conditions (temperature, 
use of buffers, time of reaction), and/or in the use of a variety of reaction substrates of measuring the enzyme activity, even for a single enzyme (Tabatabai 1994; Alef and Nannipieri 1995; Gianfreda and Bollag 1996; Schinner et al., 1996, Burns and Dick, 2002). Unfortunately, generally accepted standard procedures still do not exist (Baldrian, 2009).

The role of soil enzymes and their activities are defined by their relationships with soil and other environmental factors (e.g., acid rain, heavy metals, pesticides, and other industrial chemicals) that affect their activities (Burns, 1982; Hussain et al., 2009). Soil enzymes are the mediators and catalysts of important soil functions that include: decomposition of organic inputs; transformation of native soil organic matter; release of inorganic nutrients for plant growth; $\mathrm{N}_{2}$ fixation; nitrification; denitrification; and detoxification of xenobiotics (Dick, 1997). In addition, soil enzymes have a crucial role in $\mathrm{C}$ ( $\beta$-glucosidase and $\beta$-galactosidase), $\mathrm{N}$ (urease), $\mathrm{P}$ (phosphatase), and $\mathrm{S}$ (sulphatase) cycle (Karaca et al., 2011). Soil enzymology is nowadays of practical importance because the influence of agro-chemicals, industrial waste, heavy metals, as well as soil fertility management can be measured. Especially the search for urease inhibitor is of practical interest in order to reduce ammonia losses from soils (Schaller, 2009). The importance of soil enzymes has been explained as useful in describing and making prediction about ecosystem's function, quality and interactions among subsystems (Dick and Tabatabai, 1992). The focus of this article is to provide a review of soil enzyme activity as a biological, process-level indicator for impacts of natural and anthropogenic activities on soils. This knowledge of soil enzymology can be applicable as bioindicator to human endeavour of ecosystem perturbation, agricultural practices and xenobiotic pollution.

\section{What is bioindicator?}

A bioindicator is defined as an organism, part of an organism, the product of an organism (e.g., enzyme), collection of organisms or biological process which can be used to obtain information on the quality of all or part of the environment (Killham, 2002). A number of bioindicators have been suggested for monitoring soil health and they include: soil microbial biomass, carbon and nutrient cycling, community structure and biodiversity, soil animals, plants, and soil enzymes (Killham, 2002). Bioindicators are very important for resource managers in order to understand ecological changes within the soil ecosystem (Dale et al., 2008). Dale and Beyeler (2001) and Dale et al. (2008) summarized the criteria for ecological indicators: (i) easy to measure, (ii) sensitive to system stresses, (iii) respond to stress, (iv) anticipation of change in ecological system, (v) predicts changes, (vi) being integrative, (vii) ability to respond to natural disturbances, anthropogenic stresses and changes over time, (viii) variable with response and (ix) having the attention of measured parameters of spatial and temporal change.

Soil enzymes have been reported as useful soil quality biological indicators due to their relationship to soil biology, being operationally practical, sensitive, integrative, ease to measure and described as "biological fingerprints" of past soil management, and relate to soil tillage and structure (Bandick and Dick, 1999). They are also indicative of biological equilibrium (Frankenberger and Tabatabai, 1991), fertility (Nannipieri, 1994; Antonious, 2003), quality (Dick, 1997; Bucket and Dick, 1998), and changes in the 
biological status of soil due to pollution (Nannipieri and Bollag, 1991; Schaffer, 1993; Trasar-Cepeda et al., 2000).

\section{Some Selected Soil Enzymes used as Biological indicators}

\section{Dehydrogenase}

Dehydrogenase is an enzyme that oxidizes soil organic matter by transferring protons and electrons from substrates to acceptors. This enzyme is considered to exist as an integral part of intact cells but does not accumulate extra-cellularly in the soil (Das and Varma, 2011). Dehydrogenase activities in soil are biological indicators of overall microbial respiratory activity of soils and are used by microorganisms in the soil to break down organic matter; metabolic processes that occur in abundance in healthy microorganisms (Bolton et al., 1985). Burns (1978) reported that dehydrogenase enzyme activity is commonly used as an indicator of biological activity in soils. This enzyme occurs only within soil bacteria (e.g. genus Pseudomonas, with Pseudomonas entomophila as most abundant). They do not act on their own without a bacterial host. Therefore, when dehydrogenase is present in the soil, you can reasonably conclude that bacteria are present (Walls-Thumma, 2000).

Testing for dehydrogenase activity in soil bacteria involves adding a substance (triphenyltetrazolium chloride) to the soil that serves two purposes. First, it makes organic materials more available to microorganisms. At the same time, the bacteria convert it to a chemical called formazan, which can be extracted from the soil and analysed (Alef and Nannipieri, 1995; Walls-Thumma, 2000). Higher levels of formazan indicate that bacteria are present and healthy, undertaking the metabolic processes that boost soil fertility (Walls-Thumma, 2000). Measuring dehydrogenase levels allow researchers to better understand the effect of agricultural practices, such as pesticide use, or other management practices on the health of soil, as well as a direct measure of soil microbial activity. It can also indicate the type and significance of pollution in soils (Walls-Thumma, 2000). For example, higher activities of dehydrogenases have been reported at low doses of pesticides, and, lower activities of the enzyme at higher doses of pesticides (Baruah and Mishra, 1986). Similarly, dehydrogenase enzyme is higher in soils polluted with pulp and paper mill effluents (McCarthy et al., 1994) but low in soils polluted with fly ash (Pitchel and Hayes, 1990).

\section{B-Glucosidase}

$\beta$-glucosidase is a common and predominant enzyme in soils (Eivazi and Tabatabai, 1988; Tabatabai 1994). The enzyme plays an important role because it is involved in catalysing the hydrolysis of various $\beta$-glucosides present in plant debris decomposing in the soil ecosystem. Thus, it is named according to the type of bond that it hydrolyses (Ajwa and Tabatabai 1994; Martinez and Tabatabai 1997). This enzyme is included in the category of glucosidases that hydrolyse disaccharides. $\alpha$ Glucosidase, which catalyses the hydrolysis of $\alpha$-D-glucopyranoside, is also included among glucosidases. Other glucosidases are $\alpha$-galactosidase and $\beta$-galactosidase (also called lactase). $\beta$-glucosidase is more prominent in soil than $\alpha$-glucosidase and $\alpha$ and $\beta$ galactosidases. It is a rate limiting enzymes in microbial degradation of cellulose to glucose, an important C energy source of life for microorganisms in the soil (Esen, 1993; Tabatabai, 1994), according to the following reaction:

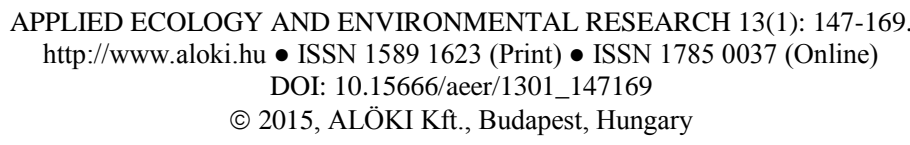




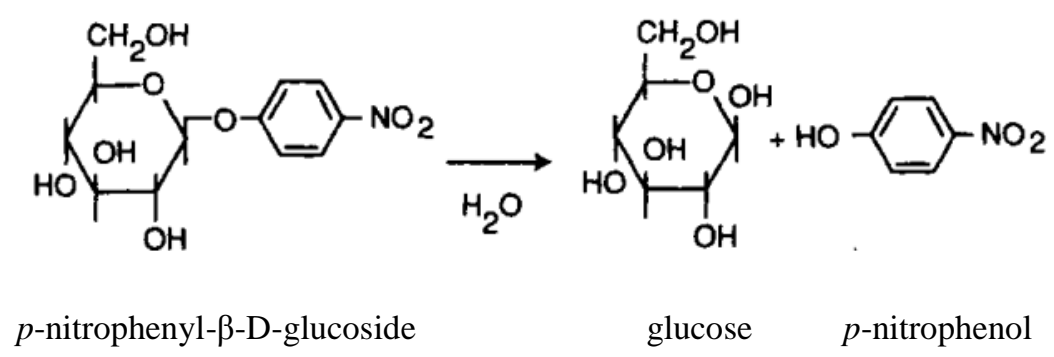

$\beta$-glucosidases are known to be widely distributed among plants, animals, fungi, bacteria and yeasts (Veena et al., 2011). Glucosidase activity has been observed in various plant species such as maize and sorghum (Verdoucq et al., 2003), roots of Panax ginseng plant (Zhang et al., 2001), and microbes like Penicillium purpurogenum (Dhake and Patil, 2005), Ceriporiopsis subvermispora (Magalhaes et al., 2006), Flavobacterium johnsonae (Okamota et al., 2000), Trichoderma spp. (Yun et al., 2001; Pragya et al., 2013), Lactobacillus plantarum (Spano et al., 2005) and Dyella koreensis spp. (An et al., 2005). There is considerable evidence suggesting that a significant fraction of $\beta$-glucosidase enzymatic activity measured in soil originates from abiontic enzymes (enzymes of biological origin no longer associated with living cells) excreted into the soil solution or immobilized enzymes of microbial origin sorbed to clays or humus colloids ((Hayano and Tubaki, 1985; Busto and PerezMateos, 1995; 2000).

The enzyme is characteristically useful as a soil quality bioindicator, and may give a reflection of past biological activity, the capacity of soil to stabilize the soil organic matter (SOM), and can be used to detect management effect on soils (Bandick and Dick, 1999; Ndiaye et al., 2000). This has greatly facilitated its adoption for soil quality testing (Bandick and Dick, 1999). Generally, $\beta$-glucosidase activities can provide advanced evidence of changes in organic carbon long before it can be accurately measured by other routine methods (Joachim and Patrick, 2008). The $\beta$ glucosidase enzyme is very sensitive to changes in $\mathrm{pH}$, and soil management practices. Acosta-Martinez and Tabatabai (2000) reported $\beta$-glucosidase as sensitive to $\mathrm{pH}$ changes, with its activity significantly $(\mathrm{P}<0.001)$ and positively correlated with soil $\mathrm{pH}$. This property can be used as a good biochemical indicator for measuring ecological changes resulting from soil acidification in situations involving activities of this enzyme. The $\beta$ - glucosidase enzyme is also known to be inhibited by heavy metal contamination such as $\mathrm{Cu}$ and several others (Joachim and Patrick, 2008). For instance, studies have shown that plant debris did not decompose or show $\beta$-glucosidase activities when exposed to heavy metal polluted soils (Joachim and Patrick, 2008). More understanding of the $\beta$-glucosidase enzyme activities and factors influencing them may contribute significantly to the studies of soil ecosystem status (Das and Varma, 2011).

\section{Cellulase}

Cellulase catalyses hydrolysis of cellulose to D-glucose (Hussain et al., 2009). Cellulose is the most abundant structural polysaccharide of plant cell walls with $\beta-1,4$ glucosidic linkages and represents almost $50 \%$ of the biomass synthesized by photosynthetic fixation of $\mathrm{CO}_{2}$ (Eriksson et al., 1990). The cellulolytic enzyme consists 
of at least three enzymes (Joachim and Patrick, 2008). They include: endo-1,4- $\beta$ glucanase which attacks the cellulose chains at random, exo-1,4- $\beta$-glucanase which removes glucose or cellobiose from the non-reducing end of the cellulose chains, and $\beta$-D-glucosidase which hydrolyses cellobiose and other water soluble cellodextrins to glucose.

The cellulolytic enzyme systems in fungi can be divided into three groups. The softrot fungi (Aspergillus niger, A. oryzae, Fusarium solani, T. harzianum, Trichoderma reesei, Trichoderma atroviride, Mucor circinelloides), brown rot fungi (Poria placenta, Coniophora puteana, Lanzites trabeum, Tyromyces palustris, Fomitopsis sp.) and white-rot fungi (Phanerochaete chrysosporium, Agaricus arvensis, Sporotrichum thermophile, Pleurotus ostreatus) (Kleman-Leyer et al., 1996; Nutt, 2006; Sukumaran et al., 2005; Kuhad et al., 2011). Cellulase enzymes in bacteria are produced by aerobic (Acinetobacter junii, Bacillus subtilis, Cellulomonas biazotea, Pseudomonas cellulose) and anaerobic (Acetivibrio cellulolyticus, Butyrivibrio fibrisolvens, Clostridium thermocellum) microbes (Sukumaran et al., 2005; Sadhu et al., 2013). Also actinomycetes (Cellulomonas fimi, Streptomyces drozdowiczii, Thermomonospora fusca) produce cellulolytic enzyme (Sukumaran et al., 2005; Kuhad et al., 2011). Most cellulolytic microbiota produces, in addition to cellulases that hydrolyse the $\beta$ (1-4) glucosidic bonds, a number of other cell-wall-degrading enzymes such as ligninases, xylanases, pectinases, etc. (Sukumaran et al., 2005). The production of cellulases is also documented in plants and in a number of invertebrate taxa that includes insects, crustaceans, annelids, molluscs, mussels and nematodes (Sadhu et al., 2013).

Activities of cellulases in agricultural soils are affected by several factors. These include temperature, soil $\mathrm{pH}$, water and oxygen contents (abiotic conditions), the chemical structure of organic matter and its location in the soil profile horizon (Deng and Tabatabai, 1994; Alf and Nannipieri, 1995), quality of organic matter/plant debris and soil mineral elements (Sinsabaugh and Linkins, 1989; Deng and Tabatabai 1994) and the trace elements from fungicides (Deng and Tabatabai 1994; Arinze and Yubedee 2000).

Demonstrating the effects of increasing concentrations of fungicides on cellulases activities, Arinze and Yubedee (2000) showed that fungicides benlate, calixin and captan inhibited cellulase activity in Fusarium monoliforme isolates. Captatol inhibited the cellulose activity in the sandy loam soil, and chlorothalonil showed a clear reduction in cellulase activity under flooded or non-flooded conditions (Joachim and Patrick, 2008). Several mechanisms have been proposed in the degradation of cellulose by cellulases. For instance, chitin in the presence of cellulose induces the synthesis of chitinase and other cell wall lytic enzymes which promote the release of the intramural $\beta$-glucosidase into the medium. All these findings suggest that the activities of cellulases can be used to give preliminary indication of some of the physical and chemical properties of soil, thus, easing agricultural soil management strategies (Joachim and Patrick, 2008). Since cellulases enzymes play an important role in global recycling of the most abundant polymer, cellulose in nature, it would be of critical importance to understand this enzyme better so that it may be used more regularly as a predictive tool in our soil fertility programmes (Das and Varma, 2011). 


\section{Urease}

Urease is an enzyme that catalyses the hydrolysis of urea into $\mathrm{CO} 2$ and $\mathrm{NH} 3$ with a reaction mechanism based on the formation of carbamate as an intermediate (Tabatabai, 1982).

$$
\mathrm{H}_{2} \mathrm{NCONH}_{2}+\mathrm{H}_{2} \mathrm{O} \rightarrow 2 \mathrm{NH}_{3}+\mathrm{CO}_{2}
$$

It also catalyses the hydrolysis of hydroyurea, dihydroxyurea and semicarbazid and contains nickel as a co-factor with its molecular weight may range from 151,000 to 480,000 Da (Alef and Nannipieri, 1995). The urease is widely distributed in nature, being present mainly from plants (Polacco, 1977) and microorganisms found as both intra- and extra-cellular enzymes (Burns, 1986; Mobley and Hausinger 1989). On the other hand, urease extracted from plants or microorganisms rapidly degraded in soil by proteolytic enzymes (Pettit et al. 1976; Zantua and Bremner 1977). This suggests that a significant fraction of pureolytic activity in the soil is carried out by extracellular urease, which is stabilized by immobilization on organic and mineral soil colloids.

The enzyme urease has been widely used to evaluate changes in soil quality related to management, since its activity increases with organic fertilization and decreases with soil tillage (Saviozzi et al., 2001). This enzyme, mostly the cases are an extra-cellular enzyme representing up to $63 \%$ of total activity in the soil (Martinez-Salgado et al., 2010). It has been shown that its activity depends on microbial community, physical, and chemical properties of soil (Corstanje et al., 2007), and its stability is affected by several factors: organo-mineral complexes and humic substances make them resistant to denaturing agents such as heat and proteolytic attack (Makoi and Ndakidemi, 2008). Urease activity is used as a soil biological indicator because it is influenced by soil factors such as cropping history, organic matter content, soil depth, management practices, heavy metals and environmental factors like temperature and $\mathrm{pH}$ (Yang et al., 2006). The effect of temperature on urea hydrolysis has received considerable research attention. Generally, urease activity increases with increasing temperature. Consequently the understanding of urease activity should provide better ways to manage urea fertilizer, especially in warm high rainfall areas, flooded soils and irrigated conditions (Makoi and Ndakidemi, 2008).

\section{Phosphatases}

Organic phosphorus $\left(\mathrm{P}_{\mathrm{o}}\right)$ is abundant in soils and can contribute to the $\mathrm{P}$ nutrition of plants and microbes following hydrolysis and the release of free phosphate (Condron et al., 2005). This process is catalysed by phosphatase enzymes, which are actively secreted into the soil by many plants and microbes in response to a demand for $\mathrm{P}$, or passively released from decaying cells (Quiquampoix and Mousain, 2005). Of the phosphatases present in soil, phosphomonoesterases are the most studied. This group of enzymes act on a range of low molecular weight $\mathrm{P}$ compounds with monoester bonds, including mononucleotides, sugar phosphates, and polyphosphates (Reid and Wilson, 1971). They cannot initiate the cleavage of phosphate from phytic acid (myoinositolhexakisphosphate), although they can catalyse the hydrolysis of lower-order inositol phosphates (Cosgrove, 1980). Phosphodiesterases are far less studied in both soils and soil organisms. This seems a significant oversight, because phosphodiesterase

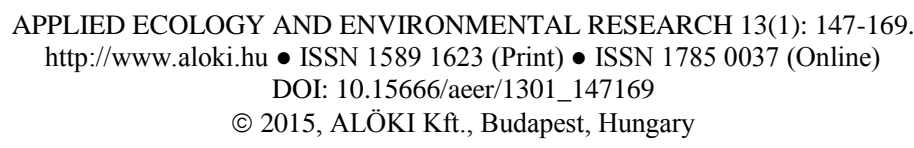


is involved in the degradation of phospholipids and nucleic acids, which constitute the majority of the fresh organic P inputs to soil (Cosgrove, 1967). Phosphomonoesterase and phosphodiesterase are both necessary to release free phosphate from a phosphate diester (Turner and Haygarth, 2005). Initial hydrolysis by phosphodiesterase releases a phosphate monoester, which must then by hydrolysed by phosphomonoesterase to release free phosphate for biological uptake (Fig. 1).

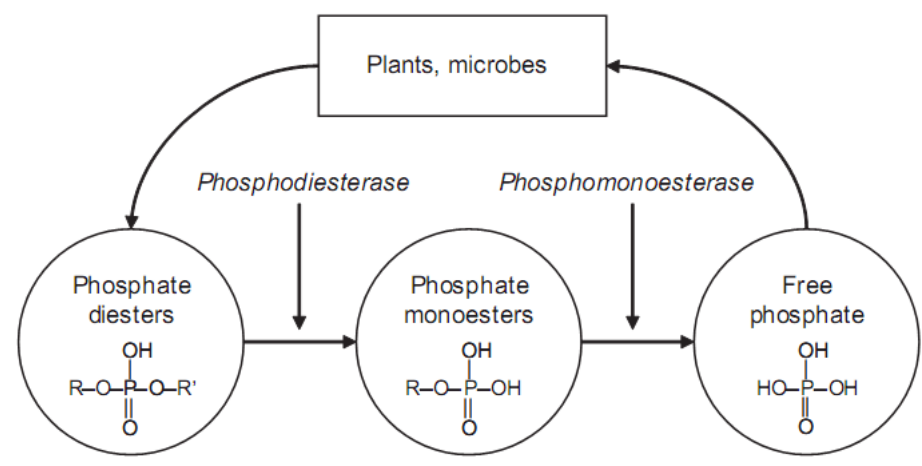

Figure 1. A simplified conceptual model of the turnover of organic phosphorus inputs from plants and microbes in soil. Organic phosphorus inputs to soil from plants and microbes are mainly phosphate diesters, which must be hydrolyzed by phosphodiesterase and phosphomonoesterase prior to the release of free phosphate for biological uptake. $R$ and $R^{\prime}$ represent organic moieties (culled from Benjamin and Philip, 2005).

Microorganisms that produce phosphates in soil includes soil fungi, particularly those belonging to the genera Aspergillus and Penicillium, along with Pseudomonas and Bacillus bacteria that produce mostly neutral phosphatase, while Actinomycetes produced only negligible quantities of phosphatases (Tarafdar and Chhonkar, 1979). In soil ecosystems, these enzymes are believed to play critical roles in $\mathrm{P}$ cycles as evidence shows that they are correlated to $\mathrm{P}$ stress and plant growth (Speir and Ross, 1978). Land plants have evolved many morphological and enzymatic adaptations to tolerate low phosphate availability. This includes the transcription activity of acid phosphatases, which tend to increase with high P stress (Miller et al., 2001; Li et al., 2002). For example, when there is a signal indicating P deficiency in the soil, acid phosphatase secretion from plant roots is increased to enhance the solubilisation and remobilisation of phosphate, thus influencing the ability of the plant to cope with P-stressed conditions (Hayes et al., 1999; Karthikeyan et al., 2002; Versaw and Harrison, 2002).

In soil, phosphomonoesterases have been the most studied enzymes probably because they have activity both under acidic and alkaline conditions, according to its optimal $\mathrm{pH}$, and because they act on low molecular P-compounds, including nucleotides, sugar phosphates and polyphosphates (Makoi and Ndakidemi, 2008); thus they can be used as soil quality bioindicators. Turner and Haygarth (2005), evaluated phosphatase activity in temperate grassland, and found a strong correlation between enzyme activity and soil properties such as $\mathrm{pH}$, total $\mathrm{N}$, organic $\mathrm{P}$ and clay content. 
The amount of acid phosphatase exuded by plant roots has been shown to differ between crop species and varieties (Izaguirre-Mayoral et al., 2002; Ndakidemi, 2006), as well as crop management practices (Wright and Reddy, 2001; Ndakidemi, 2006). For instance, research has shown that legumes secrete more phosphatase enzymes than cereal (Yadav and Tarafdar, 2001; Li et al., 2004). This may probably be due to a higher requirement of $\mathrm{P}$ by legumes in the symbiotic nitrogen fixation process as compared to cereals (Joachim and Patrick, 2008). The ability to solubilize soil mineral elements by these phosphomonoesteraces is expected to be a higher in biologically-managed systems because of a higher quantity of organic $\mathrm{C}$ found in those systems. In fact, the activity of acid and alkaline phosphatases was found to correlate with organic matter in various studies (Guan, 1989; Jordan and Kremer, 1994; Aon and Colaneri, 2001). It is, therefore, anticipated that management practices that induce $\mathrm{P}$ stress in the rhizosphere may also affect the secretion of these enzymes in the ecosystem ((Ndakidemi, 2006). Joachim and Patrick (2008) observed that there have been few studies examining the influence of management options in the ecosystem on phosphatases activity in soil where most crops are grown. Understanding the dynamics of phosphatase activities in the soil ecosystems, according to Das and Varma (2011) is crucial for predicting their interactions as their activities may, in turn, regulate nutrient uptake and plant growth.

\section{Arylsulphatase}

Arylsulfatase is the enzyme that catalyses the hydrolysis of organic sulfate ester (Kertesz and Mirleau, 2004) and is typically widespread in the soils (Tabatabai and Bremner, 1970; Gupta et al., 1993; Ganeshamurthy et al., 1995). They are classified according to the type of the ester in arylsulphatases: akylsulphatases, steroid sulphatases, glucosulphatases, chondrosulphatases and myrosulphatases (Tabatabai, 1982). The enzyme also catalyses the hydrolysis of p-nitrophenyl sulfate, potassium phenyl sulphate, potassium nitrocatechol sulphate and potassium phenolphthalein sulphate (Alef and Nannipieri, 1995).The role of this enzyme in the hydrolysis of aromatic sulphate esters to phenols and sulphate, or sulphate sulphur is shown in the following chemical equation (Tabatabai, 1994):

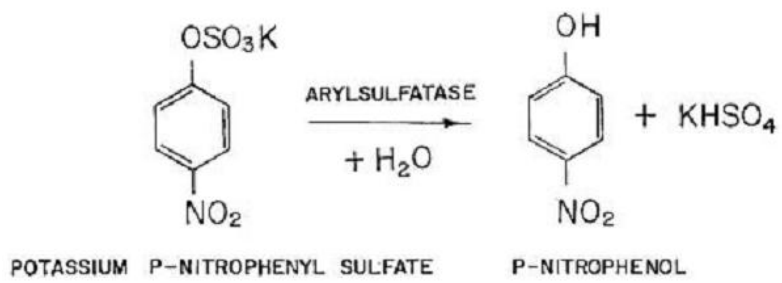

The enzyme has been detected in strains of bacteria (Actinobacteria sp., Pseudomonas sp., Klebsiella sp. and Raoultella sp.), fungi (Trichoderma sp. and Eupenicillium sp.), plants and animals (Nicholls and Roy, 1971), and was first detected in soils by Tabatabai and Bremner (1970). Arylsulphatases are secreted mainly by bacteria into the external environment as a response to sulphur limitation (McGill and Colle, 1981). Its occurrence in different soil systems is often correlated with microbial biomass (Klose and Tabatabai, 1999) and rate of S immobilization (Vong et

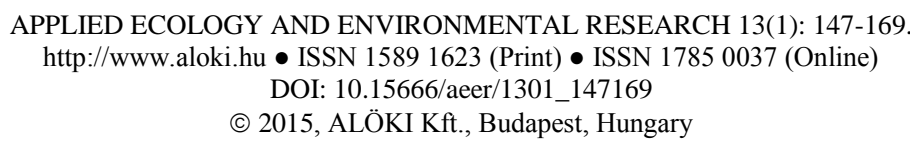


al., 2003). The release of sulphate from soluble and insoluble sulphate esters in the soil is affected by various environmental factors such as heavy metal pollution (Tyler, 1981; Kucharski, et al., 2011), pH changes in the soil solution (AcostaMartinez and Tabatabai, 2000), organic matter content and its type (Sarathchandra and Perrott, 1981; Dalal, 1982), the concentration of organic sulphate esters (Dodgson and Rose, 1976), the extent to which organic sulphate esters are protected against enzymatic hydrolysis such as sorption to particle surfaces in soils, and the activity persistence of extracellular arylsulphatases in the soil (Joachim and Patrick, 2008).

\section{Soil Enzyme Activity as a Biological Indicator of Soil Ecosystem Status}

\section{Soil Enzymes as Bioindicators of Ecosystem Perturbation}

Changing land use from one type to another generally affects the soil ecosystem status. Sicardi et al. (2004) found that land use conversion from natural grazed pastures to commercial Eucalyptus grandis plantations, showed that no significant effect was found on the number of cellulolytic aerobes, P-solubilizer and Azotobacter spp. communities, whereas significant effect was observed on soil respiration, Cmineralization coefficient, dehydrogenase, fluorescien diacetate hydrolysis and acid and alkaline phosphatase activity. Sicardi et al. (2004) also reported that land use and management practices alter the total amount and composition of soil organic matter and significantly change the enzyme activities. Natural systems changed to agricultural systems not only affect vegetation, but also biological properties are altered in soil ecosystems (Acosta-Martinez et al., 2003). They observed higher enzymatic activities ( $\beta$-glucosidase, $\beta$-glucosaminidase, arylamidase, alkaline and acid phosphatase, phosphodiesterase and arylsulphatase) in conservation reserves programme, native grassland and rotation with other crops (wheat or sorghum) when compared with continuous cotton (Acosta-Martinez et al., 2003).

Devegetation and revegetation influence soil quality when compared with undisturbed soils. In the study carried out by Bastida et al. (2006), they found that dehydrogenase and protease were lower in devegetated soils (devegetation of Pinus halepenis and natural shrubs) than undisturbed soil. Izquierdo et al. (2005) found that elimination of vegetation caused a long-term negative influence on biochemical and microbial activity of the soil. Soil quality has not been recovered even after 15 years of deforestation. They also observed that protease and $\beta$-glucosidase activities were in revegetation with Casuarina equisetifolia than with Anacardium occidentale; however, urease, protease, acid phosphatase and $\beta$-glucosidase activities were significantly greater in revegetated soil (soil restoration: after revegetation of mining area) than in bare soil 4 years after planting (Izquierdo et al., 2005).

Forest fires are considered as natural disturbances and caused the most dramatic changes in forest ecosystems (Karaca et al., 2011). Due to the low volatilization temperature of $\mathrm{N}$, most of the nitrogen found in biomass and soil is lost to the atmosphere when forest fires occur. Only some enzyme activities discriminate the fire effect on the ecosystem as bioindicators. Different soil enzymes were investigated by different researchers for discriminating fire stress on soil quality. Some activities were decreased and others were increased (Karaca et al., 2011). Invertase and proteinase activities were declined by burning, but acid phosphatase, polyphenoloxidase and peroxidase activities were increased (Zhang et al., 2005). Urease activity declined by the fire effect and this negative effect on urease activity was time dependent and

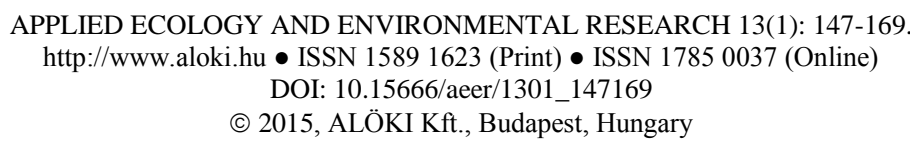


recovered after 12 years of burning (Cetin et al., 2009). Sardans et al. (2005) reported that climatic conditions influence all living things as well as soil quality. The reduction of $10 \%$ of soil moisture decreased urease (10-67\%), protease (15-66\%) and $\beta$ glucosidase (10-80\%) activities while decreasing of $21 \%$ of soil moisture decline urease (42-60\%), protease (35-54\%) and $\beta$-glucosidase (35-83\%) and acid phosphatase (31$40 \%$ ) activities and no significant influences were found on alkaline phosphatase activities. N-cycling enzymes (protease and urease) were the most influenced by drought (Sardans et al., 2005).

\section{Soil Enzymes as Bioindicators of Change in Agricultural Practices}

Fertilization of soils is conducted in soils by using different fertilizers such as mineral, manure, green manure, compost, and vermicompost. Kandeler et al. (1999) showed that farmyard manure enhanced microbial biomass, urease, deaminase and alkaline phophatase activities in soils compared with other treatments (mineral fertilizers) under rotations. They observed that stage of plant growth should be the cause of concern on enzyme activities in soils in terms of evaluating the impact of fertilizers. Similarly, soil enzyme activities (phosphatase, invertase, catalase and urease) under different fertilizers (no fertilization, organic manure, organic manure $+\mathrm{N}$, organic manure $+\mathrm{NP}$, organic manure $+\mathrm{NK}$, organic manure $+\mathrm{NPK}$ ) were lower in the early growth stage of cucumber, but enhanced in the late stages (Yang et al., 2008). Also, the type of mineral fertilizer used influence soil enzyme activity depending on the soil enzymes involved, in which there is, nutrient cycling (N, P, C, and S). Soil enzyme activities were inhibited with $\mathrm{N}$ fertilizer while they were promoted by $\mathrm{P}$ and $\mathrm{K}$ fertilizers. A decrease of urease activity could be explained by the activation of nitrification and denitrification causing suppression in urease production (Aon et al., 2001).

Organic fertilizers are used in agricultural systems, especially organic farming. Compost application is important in establishing and maintaining soil organic matter to a certain level in organic farming. Chang et al. (2007) found that soil enzyme activities (dehydrogenase, cellulase, protease, arylsulphatase, $\beta$-glucosidase, urease, arylsulphatase, and acid and alkaline phosphatases), as well as other microbial properties increased significantly in compost-treated soil compared with chemicalfertilizer soils; however, no significant evaluation was observed in studied enzyme activities after the compost dose of $540 \mathrm{Kg} \mathrm{N} \mathrm{ha}^{-1} \mathrm{yr}^{-1}$. Saha et al. (2008) observed that dehydrogenase activity is higher in composted cattle manure (44-200\%) and vermicompost (22-108\%) than in control. They concluded that: (i) organic applications, enhanced organic matter contents and microbial biomass and thus provide better potential for higher enzyme production and greater enzyme activities. (ii) additions of organic amendments showed different responses on soil enzyme activities depending on the organic matter type, and (iii) addition of organic amendments (cattle manure, compost or vermicompost) improve soil quality, increase soil organic matter content and stimulate biological and biochemical properties (Saha et al., 2008).

Organic amendments influence soil microbes and biochemical properties in different ways depending on the nutrient content. Rajashekhararao and Siddaramappa (2008) found that application of higher rates of organic amendments (rice residue and tree litters, high $\mathrm{C}$ content) was favourable to soil quality parameters (microbial biomass, microbial quotients, urease and acid phosphatase activities). Although they evaluated the other soil health parameters (extraction yield of humus and composition of humus),

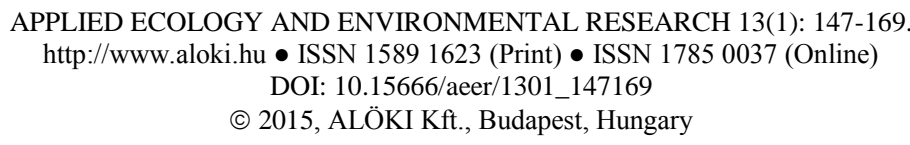


and observed that microbial quotient was the most sensitive indicator for reflecting the decline in soil quality. The authors also reported that microbial biomass; microbial quotient and soil enzyme activities are used for measuring biological soil quality as parameters. Addition of different carbon sources enhanced urease activity at different levels of elevation depending on $\mathrm{N}$ levels. Higher level of $\mathrm{N}$ stimulated urease activity in different $\mathrm{C}$ sources (Rajashekhararao and Siddaramappa, 2008).

Organic amendments can be used for suppression of plant diseases. Root rot severity was strong, adversely correlated with total $\mathrm{C}$, arylsulfatase, $\beta$-glucosidase activities (Leon et al., 2006). $\beta$-glucosidase was not accepted as a useful indicator of disease suppression because it varied over time. Arylsulfatase was the best bioindicator for reflecting disease suppression. They indicated that applying organic amendments to soil can cause disease suppression by enhancing antagonist micro-organisms and microbial biomass and activity can be related to microbial competition with pathogens (Leon et al., 2006).

Tillage application may change soil quality through altering soil physico-chemical, hydrological, microbiological and biochemical properties and thus influences soil microbial community diversity and the production of soil enzymes. Tillage also affects soil nutrient levels and its availability, distribution of organic matter in the soil profile, soil water and oxygen content and soil fertility (Karaca et al., 2011). Tillage especially influences soil organic matter by exposing more soil organic matter to microbial attack and finally rapid loss of soil organic matter. Losing soil organic matter causes a decline of crop productivity, increase soil erosion and reduction in soil biological activity that negatively affects soil enzymes. To sum, tillage causes a great perturbation in soil environments (Madejon et al., 2007; Karaca et al., 2011). Many researchers conducted the impact of tillage on soil quality parameters as well as soil enzymes. Dehydrogenase activity increased under continuous zero-tillage practices and alkaline phosphatase and protease activities were higher in the zero-tillage systems over conventional practice; however, cellulase activity was greater in conventional practice compared to other management (Mina et al., 2008). No-till systems provide better enzyme activities in soils. Deng and Tabatabai (1997) showed that acid phosphates, alkaline phosphates, phosphodiesterase, inorganic pyrophosphatase, and arylsulfatase were significantly higher in no-till/double mulch than in other treatments (no-till/bare, no-till/normal, chisel/normal, chisel/mulch, mouldboard/normal, mouldboard/mulch).

Soil enzyme activities are accepted early and are more reliable bioindicators than soil physico-chemical properties under different tillage systems. Curci et al. (1997) evaluated the influence of conventional tillage systems (shallowing plowing: $20 \mathrm{~cm}$, deep plowing: $40 \mathrm{~cm}$ and scarification: $50 \mathrm{~cm})$ at different depth $(0-20,20-40,40-50$, $50-70 \mathrm{~cm}$ ) on soil enzyme activities (acid phosphatase, alkaline phosphatase, phosphodiesterase, pyrophosphatase, arylsulfatase, dehydrogenase, $\alpha$-and $\beta$-glucosidase, $\alpha$-and $\beta$-galactosidase, urea and nitrate reductase). The result showed that: (i) glucosidase, galactosidase, nitrate reductase and dehydrogenase activities were influenced by tillage systems, (ii) their activities were greater in shallow plowing and scarification than deep plowing plots in the upper layer $(0-20 \mathrm{~cm})$ of soil and (iii) no significant differences were found in the physical-chemical properties of the soil under different tillage systems (Curci et al., 1997).

Irrigation as one of the agricultural practices that provides adequate moisture level in the soil for plant growth affects the soil enzymatic activities. Zhang and Wang (2006) investigated the impact of subsurface irrigation $\left(\begin{array}{lllll}-10 & -16 & -25 & -40 & -63 \mathrm{KPa}\end{array}\right)$ on

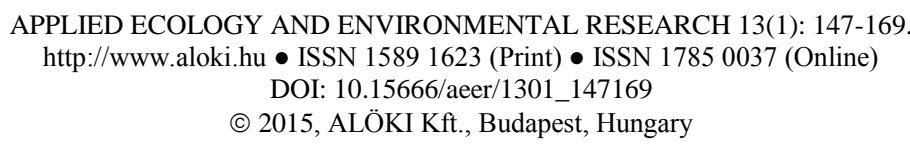


phosphatase, urease and catalase under tomato cultivated in greenhouse experiment. They found that phosphatase and catalase activities increased in more frequent irrigation $(-10$ and $-16 \mathrm{KPa})$ and urease activity decreased under irrigation.

\section{Soil Enzymes as Bioindicators of Xenobiotic Pollution}

Xenobiotics are by definition unnatural compounds (e.g. pesticides, industrial wastes) but the wider definition include naturally occurring compounds (e.g. heavy metals) that are synthesized or are present in unnaturally high concentrations in the environment (Skladany and Metting, 1993). Such compounds are of crucial concern in the soil environment as they could affect many biological and biochemical reactions in soils (Dick, 1997). Pesticides, which include herbicides, fungicides, and insecticides etc., introduced into the environment, have potential to affect non-target organisms and soil biochemical processes.

Pesticides reaching the soil may disturb local metabolism or enzymatic activities (Engelen et al., 1998; Liu et al., 2008), and its applications have been shown to both negative and positive effects on enzyme activity in soils (Ladd, 1985). The negative impact of pesticides on soil enzymes (hydrolases, oxidoreductases, and dehydrogenase) activities has been widely reported in the literature (Ismail et al., 1998; Monkiedje et al., 2002; Menon et al., 2005). There is also evidence that soil enzyme activities and ATP contents are increased by some pesticides (Shukla, 1997; Megharaj et al., 1999). ATP contents correlate with specific soil enzyme activities and may provide valuable information on trends in transformation of pesticides in soils (Kanazawa and Filip, 1986). A number of factors, for example, chemical nature of pesticides, the concentration used, microbial community structure, type of soil, and soil conditions can contribute to divergent research findings (Hussain et al., 2009). Malkomes (1997) attributed such differences to the dual behaviour of pesticides (both harmful and beneficial for soil enzymes), diversity and various stages of the processes taking place in soil that are frequently overlapped.

When pesticides are applied at recommended field rates, short-term studies often show an initial stimulatory, but small, effect on dehydrogenase activity: this may or may not occur with other enzymes (Dick, 1997). In relation to the effects of pesticides in soils, the two most widely-studied enzymes other than deydrogenase are phosphatase and urease. Again, short-term studies involving applications of pesticides to soils at recommended dosages for periods ranging from a few days up to 8 weeks have shown slight increases or no significant effect on the activity of these two enzymes (Baruah and Mishra, 1986; Tu, 1993). These results might be expected because these enzymes are known to exist as abiontic enzymes and thus, unless there was a direct effect on the enzyme reaction, there should be little effect on an abiontic enzyme (Dick, 1997).

To overcome the confounding effect of the multiple sources of isoenzymes in soils, studies have been conducted on the effect of pesticides on pure enzymes. Gianfreda et al. (1993) studied the effect of three herbicides and one insecticide on pure enzymes in free solution and found that responses could not be generalized were enzyme and pesticide are specific. For example, glyphosate and paraquat showed a marked activation of invertase activity, but urease and phosphatase activities were unaffected by these pesticides. Carbaryl inhibited urease and invertase activities, but had no effect on the activity or the kinetics of acid phosphatase. Atrazine did not affect the kinetics of urease, phosphatase or invertase except at very high 
concentrations. Further work showed that the 'state of an enzyme' can affect its activity in response to the presence of a pesticide. The purified urease was unaffected by paraquat or glyphosate, but urease activity complexes on montmorillonite increased in the presence of paraquat or glyphosate (Gianfreda et al., 1994). It was hypothesized that the pesticide displaced some inactive/immobilized urease from the clay surface which regained catalytic capabilities upon release into solution. These simplified systems show the complexity of the mechanisms involved in pesticideenzyme interactions (Gianfreda et al., 1994).

When pesticides are applied to soils at very high concentrations such as when there is an accidental spill, enzyme activities have been significantly affected. Alachlor $\left(10,000 \mathrm{mg} \mathrm{kg}^{-1}\right)$ alone or in mixture with atrazine and metolachor severely depressed dehydrogenase activity for 125 days, whereas esterase was only affected by the herbicide mixture (Dzantor and Felsot, 1991). Although bacterial numbers recovered, fungal numbers were still inhibited 90 days after the pesticide was applied. Adding the herbicide imaxethapyr at 100 times the recommended rate to soil showed decreases in microbial biomass $-\mathrm{C}$ and dehydrogenase activity, whereas hydrolytic enzyme activities (protease and 3,6'- diacetylfluorescein hydrolysis, FDA; a broad spectrum enzyme assay) showed corresponding increases up to 15 weeks after application of the herbicide (Perucci and Scarponi, 1994). In this case, Perucci and Scarponi (1994) hypothesized that the hydrolytic enzymes were released during lysis of microbial cells killed by imaxethapyr.

The difference between the enzymatic response at low and high pesticide concentration is due to the persistence of the pesticide which results in the inability of microbial populations to degrade or flourish in its presence (Junk et al., 1984; Schoen and Winterlin, 1987). For example, Junk et al. (1984) found that alachlor and atrazine applied alone or in combination at rates of 15 or $300 \mathrm{mg} \mathrm{kg}^{-1}$ soil showed no degradation after 68 weeks. Dzantor and Felsot (1991) reported that an emulsifiable concentrate of alachlor $\left(10,000 \mathrm{mg}\right.$ a.i. $\left.\mathrm{kg} \mathrm{soil}^{-1}\right)$ was stable for 337 days, which caused depressed bioactivity (dehydrogenase and esterase activity) and reduced bacterial and fungal numbers. Felsot and Dzantor (1995) suggested that high pesticide concentrations cause biotoxicity and that the addition of nutrients in the form of organic amendments to pesticide-contaminated soils appeared to stimulate pesticide degradation. This further indicated that some specific microbial species could survive these high concentrations and that readily-available nutrients may be limiting in pesticide-contaminated soil.

Although single applications of pesticides have shown minimal effects on soil biological properties, it may be more important to consider the effects of repeated applications over many years. Voets et al. (1974) showed that long- term atrazine applications significantly reduced the activity of phosphatase, invertase, Pglucosidase, and urease in soils. They hypothesized that this was due to reduction of biological activity rather than a direct effect on the catalytic behaviour of these enzymes. Rai (1992) found that the effect of long-term (15 years) applications of 2, 4-D on dehydrogenase and urease activity depended on application formulation. The waterbased dimethylamine salt formulation plus 2,4-D showed little effect on the activity of these enzymes over the control, whereas the 2,4-D oil-based isoctyl ester formulation significantly depressed activity of these enzymes. This was thought to be due to toxic metabolite(s) formed during degradation of the ester (Rai, 1992). 
Alternatively, the amine may stimulate microbial degradation of 2, 4-D as evidenced by increased soil respiration.

Environmental pollution of soils with heavy metals and trace elements has been reported to have toxic effects on soil biology and to affect soil biochemical processes (Dick, 1997). The sources of these contaminants can come from repeated applications of sewage sludge, municipal wastes, smelting wastes, electroplating industry wastes, impurities in fertilizers, and deposition from air pollutants such as burning of fossil fuels and various industrial activities. Dick (1997) reported that enzyme reactions are inhibited by metals: (i) through complexation of the substrate; (ii) by combining with the protein-active groups of the enzymes; or (iii) by reacting with the enzyme-substrate complex. The mode of action of metals varies with enzyme and little is known about the exact mechanisms of interactions of metals and the multitude of enzymes that can exist in soils (Dick, 1997). Some ions can act as cofactors or activators and at certain concentrations can increase the activity of some enzymes (e.g. $\mathrm{Mg}, \mathrm{Ca}, \mathrm{Ba}, \mathrm{CO}, \mathrm{Ni}, \mathrm{Zn}$ and $\mathrm{Mn}$ for pyrophosphatase; Dick and Tabatabai, 1983). Sulphydral groups of enzymes serve as catalytic sites or as groups involved in maintaining the correct conformation of the protein. Metals can react with sulphydral groups causing inactivation or inhibition of enzyme activity. In studies where a wide range of trace elements has been tested, $\mathrm{Hg}, \mathrm{Ag}, \mathrm{Cr}$ and $\mathrm{Cd}$ have generally caused the greatest inhibition of sulphatase, L-glutaminase, cellulase, L-asparginase, and P-glucosidase (Deng and Tabatabai, 1995).

Kucharski, et al. (2011) in their study of changes in the enzymatic activity in sandy loam soil exposed to $\mathrm{Zn}$ pressure found that soil contamination with zinc in doses from 70 to $10,000 \mathrm{mg} \mathrm{kg}^{-1} \mathrm{~d} . \mathrm{m}$. of soil causes highly significant inhibition of the activity of arysulphatase, dehydrogenases, acid phosphatase, urease and $\beta$-glucosidase activity. In respect to their sensitivity to soil contamination with zinc, the enzymes can be ordered as follows: arysulphatase $>$ dehydrogenases $>$ acid phosphatase $>$ urease $>\beta$ glucosidase. They hypothesized that the increased inhibition by $\mathrm{Zn}$ of enzymes was likely caused by the larger deprotonation of the sulfhydryl groups in enzyme proteins which enhance the interactions between the enzyme molecules (Eq.1). Zinc contamination causes persistent changes in the soil environment, but according to an index of resilience (RL), dehydrogenases are the first to return to the normal state of equilibrium $(\mathrm{RL}=0.276)$, while arysulphatase takes longer $(\mathrm{RL}=0.173)$ and acid phosphatase is the least resilient $(\mathrm{RL}=0.064)$. Urease, instead of having its activity improved in time, becomes increasingly disturbed $(R L=-0.350)$. Kucharski, et al. (2011) also reported that soil acidification reinforces the negative effect of zinc contamination most evidently in respect to the activity of $\beta$-glucosidase and arysulphatase.

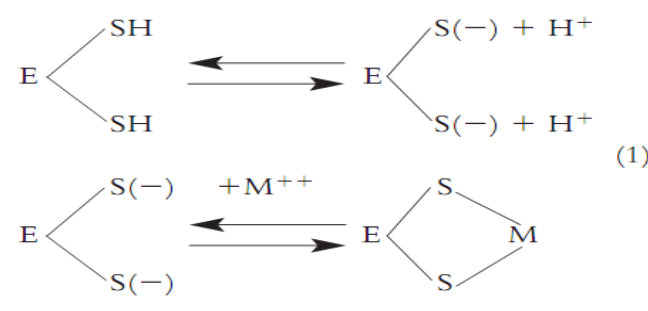


Another important factor associated with the toxicity of heavy metals is the oxidation state of an element. For example, Speir et al. (1995) observed that Cr (III) is significantly less toxic to soil biological properties than $\mathrm{Cr}$ (V1) because of Cr (III)'s tendency to undergo precipitation, complexation or fixation reactions in soils. Cr (VI) is a powerful oxidizing agent which can cause enzyme degradation by oxidation of structural linkages and has been shown to cause irreversible inhibition of urease in soils (Speir et al., 1995).

\section{Conclusion}

Soil enzymes have been reported as useful soil quality bioindicators due to their relationship to soil biology, being operationally practical, sensitive, integrative, ease to measure and described as "biological fingerprints" of past soil management, and relate to soil tillage and structure. They are also indicative of biological equilibrium, fertility, quality and changes in the biological status of soil due to pollution. Their activities may, however, be influenced by unknown natural and anthropogenic activities either in a major or minor amount. Studies focusing the discovery of new enzymes from microbial diversity in the soil might be the most suitable practices that may positively influence their activities for improved soil ecosystem status.

\section{REFERENCES}

[1] Acosta-Martínez, V., Tabatabai, M.A. (2000): Enzyme Activities in a Limed Agricultural Soil. - Biol. Fert. Soils 31: 85-91.

[2] Acosta-Martínez, V., Klose, S., Zobeck, T.M. (2003): Enzyme Activities in Semiarid Soils under Conservation Reserve Program, Native Rangeland, and Cropland. - J. Plant Nutr. Soil Sci. 166:699-707.

[3] Ajwa, H.A., Tabatabai, M.A. (1994): Decomposition of different Organic Materials in Soils. - Biol. Fertil. Soils 18:175-182.

[4] Alef, K., Nannipieri, P. (1995): Methods in Applied Soil Microbiology and Biochemistry. - Academic Press.

[5] An, D.S., Im, W.T., Yang, H.C., Yang, D.C., Lee, S.T. (2005): Dyella koreensis sp. Nov., a $\beta$-glucosidase Producing Bacterium. - Int. J. Systematic Evol. Microbiol. 55: 16251628 .

[6] Antonious, G. F. (2003): Impact of Soil Management and two Botanical Insecticides on Urease and Invertase Activity. - J. Environ. Sci. Health B 38: 479-488.

[7] Aon, M.A., Colaneri, A.C. (2001): Temporal and Spatial Evolution of Enzymatic Activities and Physico-Chemical Properties in an Agricultural soil. - Appl. Soil Ecol. 18: 255-270.

[8] Aon, M.A., Cabello, M.N., Sarena, D.E., Colaneri, A.C., Franco, M.G., Burgos, J.L., Cortassa, S. (2001): Spatio-Temporal Patterns Of Soil Microbial And Enzymatic Activities In An Agricultural Soil. - Applied Soil Ecology 18 (3): 239-254.

[9] Arinze, A.E., Yubedee, A.G. (2000): Effect of Fungicides on Fusarium Grain Rot and Enzyme Production in Maize (Zea mays L.). - Glob. J. Appl. Sci. 6(4): 629-634.

[10] Baldrian, P. (2009): Microbial Enzyme-Catalysed Processes in Soils and their Analysis. Plant Soil Environ. 55 (9): 370-78.

[11] Bandick, A.K., Dick, R.P. (1999): Field Management Effects on Soil Enzyme Activities. - Soil Biol Biochem. 31:1471-1479. 
[12] Baruah, M., Mishra, R.R. (1986): Effect of Herbicides Butachlor, 2,4-d and Oxyfluorfen on Enzyme Activities and $\mathrm{CO}_{2}$ Evolution in Submerged Paddy Field Soil. - Plant Soil 96: 287-291.

[13] Bastida, F., Moreno, J.L., Hernandez, T., Garcia, C. (2006): Microbiological Activity in a 15 Years after its Devegetation. - Soil Biol Biochem. 38:2503-2507.

[14] Benjamin, L.T., Philip, M.H. (2005): Phosphatase Activity in Temperate Pasture Soils: Potential Regulation of Labile Organic Phosphorus Turnover by Phosphodiesterase Activity. - Science of the Total Environment 344:27- 36.

[15] Bollag, J.M., Liu, S.Y. (1990): Biological Transformation Processes of Pesticides. - In: Pesticides in the Soil Environment. - Soil Science Society of America, Book Series no. 2.

[16] Bolton, H., Elliot, L. F., Papendick, R. I., Bezdicek, D. F. (1985): Soil Microbial Biomass and Selected Soil Enzymes Activities: Effect of Fertilization and Cropping Practices. Soil Biol. Biochem. 17: 297-302.

[17] Bucket, J. Z., Dick, R. P. (1998): Microbial and Soil Parameters in Relation to N Mineralization in Soils of Diverse Genesis under Differing Management Systems. - Biol. Fertil. Soils 27: 430-438.

[18] Burns, R.G. (1978): Enzyme Activity in Soil: Some Theoretical and Practical Considerations. - In: Bums, R.G. (ed.) Soil Enzymes, Academic, London.

[19] Burns, R. G. (1982): Enzyme Activity in Soil: Location and a Possible Role in Microbial Ecology. - Soil Biol. Biochem. 14: 423-427.

[20] Burns, R.G. (1986): Interaction of Enzymes with Soil Mineral and Organic Colloids. - In: Huang, P.M., Schnitzer, M. (eds.) Interactions of Soil Minerals with Natural Organics and Microbes. Soil Science Society of America, Madison.

[21] Burns, R.G., Dick, R.P. (2002): Enzymes in the Environment. - Marcel Dekker, New York.

[22] Busto, M.D., Perez-Mateos, M. (1995): Extraction of Humic- $\beta$-glucosidase Fractions from Soil. - Biol. Fert. Soils 20: 77-82.

[23] Busto, M.D., Perez-Mateos, M. (2000): Characterisation of $\beta$-D-glucosidase Extracted from Soil Fractions.- Eur. J. Soil Sci. 51:193-200.

[24] Cetin, C.S., Ekinci, H., Kavdir, Y., Yuksel, O. (2009): Using Soil Urease Enzyme Activity as Soil Quality for Reflecting Fire Influence in Forest Ecosystem. - Fresen Environ Bull (communicated).

[25] Chang, E.H., Chung, R.S., Tsai, Y.H. (2007): Effect of Different Application Rates of Organic Fertilizer on Soil Enzyme Activity and Microbial Population. - Soil Sci Plant Nutr. 53:132-140.

[26] Condron, L.M., Turner, B., Cade-Menun, B.J. (2005): Chemistry and Dynamics of Soil Organic Phosphorus. - In: Sims, T., Sharpley, A.N., (eds.) Phosphorus: Agriculture and the Environment, Madison (Wisconsin, USA) 7 American Society of Agronomy.

[27] Corstanje, R., Schulin, R., Lark, R. (2007): Scale - dependent Relationships between Soil Organic Matter and Urease Activity. - European Journal of Soil Science 58 (5): 1087-95.

[28] Cosgrove, D.J. (1967): Metabolism of Organic Phosphates in Soil. - In: McLaren, A.D., Peterson, G.H. (eds.) Soil Biochemistry, Vol. 1. New York, USA7 Marcel Dekker.

[29] Cosgrove, D.J. (1980): Inositol Phosphates: Their Chemistry, Biochemistry and Physiology. - Amsterdam, the Netherlands7 Elsevier.

[30] Curci, M., Pizzigallo, M.D.R., Crecchio, C., Mininni, R. (1997): Effects of Conventional Tillage on Biochemical Properties of Soils. - Biol. Fertil. Soils 25: 1-6.

[31] Dalal, R.C. (1982): Effect of Plant Growth and Addition of Plant Residues on the Phosphatase Activity in Soil. - Plant Soil. 66: 265-269.

[32] Dale, V.H., Beyeler, S.C. (2001): Challenges in the Development and use of Ecological Indicators. - Ecol Indic. 1:3-10.

[33] Dale, V.H., Peacock, A.D., Garten, C.T., Sobek, F., Walfe, A.K. (2008): Selecting Indicators of Soil, Microbial and Plant Conditions to Understand Ecological Changes in Georgia Pine Forests. - Ecol Indic. 8:818-827.

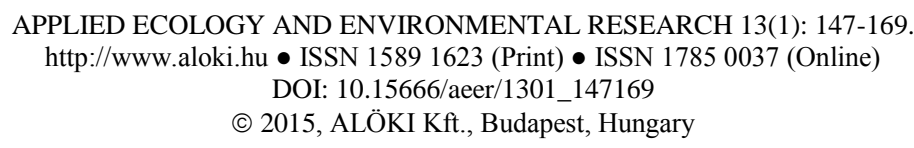


[34] Das, S. K., Varma, A. (2011): Role of Enzymes in Maintaining Soil Health. - In: Shukla, G., Varma, A. (eds.) Soil Enzymology, Soil Biology 22, Springer-Verlag Berlin Heidelberg USA.

[35] Deng, S.P., Tabatabai, M.A. (1994): Cellulase Activity of Soils. - Soil Biol Biochem. 26:1347-1354.

[36] Deng, S.P., Tabatabai, M.A. (1995): Cellulase Activity of Soils: Effect of Trace Elements. - Soil Biol Biochem. 27: 977-979.

[37] Deng, S.P., Tabatabai, M.A. (1997): Effect Of Tillage and Residue Management on Enzyme Activities in Soils: III. Phosphatase and Arylsulfatase. - Biol Fertil Soils 24:141146.

[38] Dhake, A.B., Patil, M.B. (2005): Production of $\beta$-glucosidase by Penicillium purpurogenum, Braz. - J. Microbiol. 36: 170-176.

[39] Dick, W.A., Tabatabai, M.A. (1983): Activation of Soil Pyrophosphatase by Metal ions. Soil Biology and Biochemistry 15: 59-363.

[40] Dick, W. A., Tabatabai, M. A. (1992): Significance and Potential uses of Soil Enzymes. In: Metting, F.B. Jr. (ed.) Soil Microbial Ecology. Marcel Decker, Inc., New York, USA.

[41] Dick, R.P. (1997): Soil Enzyme Activities as Integrative Indicators of Soil Health. - In: Pankhurst, C. E., Doube, B. M., Gupta, V.V.S.R. (eds.) Biological Indicators of Soil Health, CABI Publishing. USA.

[42] Dodgson, K.S., Rose, F.A. (1976): Sulfohydrolases. - In: Greenberg, D.M. (ed.) Metabolism of Sulphur Compounds, Vol. 7, Metabolic Pathways, Academic Press, London.

[43] Doran, J.W., Zeiss, M.R. (2000): Soil Health and Sustainability: Managing the Biotic Component of Soil Quality. - Appl Soil Ecol. 15: 3-11.

[44] Dzantor, E.K., Felsot, A.S. (1991): Microbial Responses to Large Concentrations of Herbicides in Soil. - Environmental Toxicology and Chemistry 10: 649-655.

[45] Eivazi, F., Tabatabai, M.A. (1988): Glucosidases and Galactosidases in Soils. - Soil Biol Biochem. 20:601-606.

[46] Engelen, B., Meinken, K., von Wintzingerode, F., Heuer, H., Malkomes, H. P., Backhaus, H. (1998): Monitoring Impacts of a Pesticide Treatment on Bacterial Soil Communities by Metabolic and Genetic Fingerprinting in Addition to Conventional Testing Procedures. - Appl. Environ. Microbiol. 64: 2814-2821

[47] Eriksson, K.E.L., Blancbette, R.A., Ander, P. (1990): Biodegration of Cellulose. - In: Eriksson, K.E.L., Blanchette, R.A., Ander, P. (eds.) Microbial and Enzymatic Degradation of Wood and Wood Components. Springer, New York.

[48] Esen, A. (1993): $\beta$-glucosidases: Overview. - In: Esen, A. (ed.) $\beta$-glucosidases and Molecular Biology, American Chemical Society, Washington, DC.

[49] Felsot, A.S., Dzantor, E.K. (1995): Effect of Alachlor Concentration and an Organic Amendment on Soil Dehydrogenase Activity and Pesticide Degradation Rate. Environmental Toxicology and Chemistry 14: 23-28.

[50] Frankenberger, W.T., Dick, W.A. (1983): Relationship between Enzyme Activities and Microbial Growth and Activity Indices in soil. - Soil Sci. Amer. J. 47:945-951.

[51] Frankenberger, W. T., Tabatabai, M. A. (1991): 2-Glutaminase Activity of Soils. - Soil Biol. Biochem. 23: 869-874.

[52] Gianfreda, L., Sannino, F., Filazzola, M.T., Violante, A. (1993): Influence of Pesticides on the Activity and Kinetics of Invertase, Urease and Acid Phosphatase Enzymes. Pesticide Science 39: 237-244.

[53] Gianfreda, L., Sannino, F., Ortega, N., Nannipieri, P. (1994): Activity of Free and Immobilized Urease in Soil: Effects of Pesticides. - Soil Biology and Biochemistry 26: 777-784.

[54] Gianfreda, L., Bollag, M.J. (1996): Influence of Natural and Anthropogenic Factors on Enzyme Activity in Soil. - In: Stotzky, G., Bollag, J.M. (eds.) Soil Biochemistry, Vol. 9, Marcel Dekker, New York.

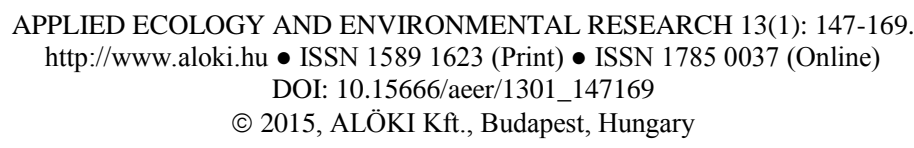


[55] Ganeshamurthy, A.M., Singh, G., Singh, N.T. (1995): Sulphur Status and Response of Rice to Sulphur on some Soils of Andaman and Nicobar Islands. - J. Indian Soc. Soil Sci. 43: 637-641.

[56] Guan, S.Y. (1989): Studies on the Factors Influencing Soil Enzyme Activities: Effect of Organic Manures on Soil Enzyme Activities and N and P Transformations. - Acta Pedol. Sinica 26: 72-78.

[57] Gupta, V.V.S.R., Farrell, R.E., Germida, J.J. (1993): Activity of Arylsuphatases in Saskatchewan Soils. - Can. J. Soil Sci. 73: 341-347.

[58] Hayano, K., Tubaki, K. (1985): Origin and Properties of $\beta$-glucosidase Activity of Tomato Field Soil. - Soil Biol. Biochem. 17: 553-557.

[59] Hayes, J.E., Richardson, A.E., Simpson, R.J. (1999): Phytase and Acid Phosphatases Activities in Roots of Temperate Pasture Grasses and Legumes. - Austr. J. Plant Physiol. 26: 801-809.

[60] Hussain, S., Siddique, T., Saleem, M., Arshad, M., Khalid, A. (2009): Impact of Pesticides on Soil Microbial Diversity, Enzymes, and Biochemical Reactions. - Advances in Agronomy 102: 160-190.

[61] Ismail, B. S., Yapp, K. F., Omar, O. (1998): Effects of Metsulfuron-Methyl on Amylase, Urease, and Protease Activities in two Soils. - Aust. J. Soil Res. 36: 449-456.

[62] Izaguirre-Mayoral, M.L., Flores, S., Cabrillo, O. (2002): Determination of Acid Phosphatases and Dehydrogenase Activities in the Rhizosphere of Nodulated Legume Species Native to two Contrasting Savannah Sites in Venezuela. - Biol. Fert. Soils 35: 470-472.

[63] Izquierdo, I., Caravaca, F., Alguacil, M.M., Hernández, G., Roldán, A. (2005): Use of Microbiological Indicators for Evaluating Success in Soil Restoration after Revegetation of a Mining Area under Subtropical Conditions. - Applied Soil Ecology 30 (1): 3-10.

[64] Joachim, H. J., Patrick, A. N. (2008): Selected Soil Enzymes: Examples of their Potential Roles in the Ecosystem. - Afr. J. Biotechnol. 7 (3):181-191.

[65] Jordan, D., Kremer, R.J. (1994): Potential use of Microbial Activity as an Indicator of Soil Quality. - In: Pankhurst, C.E., Double, B.M., Gupta, V.V.S.R., Grace, P.R. (eds.) Soil Biota Management in Sustainable Farming Systems, CSIRO Australia.

[66] Junk, C.A., Richard, I.I., Dahm, P.A. (1984): Degradation of Pesticides in Controlled Water-Soil Systems. - In: Krueger, R.F., Seiber, J.N. (eds.) Treatment and Disposal of Pesticide Wastes. ACS Symposium Series 259, American Chemical Society, Washington, DC.

[67] Kanazawa, S., Filip, Z. (1986): Distribution of Microorganisms, Total Biomass, and Enzyme Activities in Different Particles of Brown Soil. - Microbiol. Ecol. 12: 205-215.

[68] Kandeler, E., Tscherko, D., Spiegel, H. (1999): Long-term Monitoring of Microbial Biomass, N Mineralization and Enzyme Activities of a Chernozem under Different Tillage Management. - Biol Fertil Soils 28:343-351.

[69] Karaca, A., Cema, C.C., Turgay, O.C., Kizilkaya, R. (2011): Soil Enzymes as Indicator of Soil Quality. - In: Shukla, Varma, G. A. (eds.) Soil Enzymology, Soil Biology 22, Springer-Verlag Berlin Heidelberg USA.

[70] Karthikeyan, A.S., Varadarajan, D.K., Mukatira, U.T., D’Urzo, M.P., Damaz, B., Raghothama, K.G. (2002): Regulated Expression of Arabidopsis Phosphate Transporters. - Plant Physiol. 130: 221-233.

[71] Kertesz, M.A., Mirleau, P. (2004): The Role of Soil Microbes in Plant Sulphur Nutrition. - J. Exp. Bot. 55(404): 1939-1945.

[72] Killham, K. (2002): Bioindicators and Sensors of Soil Health and the Application of Geostatistics. In: Burns, R.G., Dick, R.P. (eds.) Enzymes in the Environment: Activity, Ecology and Applications. Marcel Dekker, Inc., USA.

[73] Kleman-Leyer, K.M., Siika-Aho, M., Teeri, T.T., Kirk, T.K. (1996): The Cellulases Endoglucanase I and Cellobiohydrolase II of Trichoderma Reesei Act Synergistically to

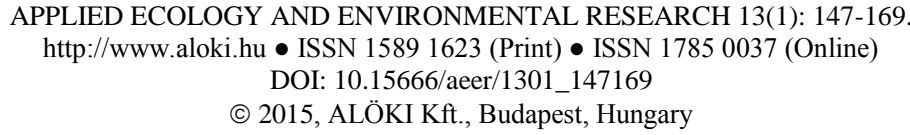


Solubilize Native Cotton Cellulose but not to Decrease its Molecular Size. - Appl Environ Microbiol 62: 2883-2887.

[74] Klose, S., Tabatabai, M.A. (1999): Arylsulphatase Activity of Microbial Biomass in Soils. - SSSAJ 63: 569-574.

[75] Kucharski, J., Wieczorek, K., Wyszkowska, J. (2011): Changes in the Enzymatic Activity in Sandy Loam Soil Exposed to Zn Pressure. - J. Elem. S. 577-589.

[76] Kuhad, R.C., Gupta, R., Singh, A. (2011): Microbial Cellulases and their Industrial Applications. - Enzyme Research, Sage-Hindawi Access to Research.

[77] Ladd, J.N. (1985): Soil Enzymes. - In: Vaughan, D., Malcolm, R.E. (eds.) Soil Organic Matter and Biological Activity. Martinus Nijhoff, Boston.

[78] Leon, M.C.C., Stone, A., Dick, R. P. (2006): Organic Soil Amendments: Impacts on Snap Bean Common Root Rot (Aphanomyes euteiches) and Soil Quality. - Applied Soil Ecology 31 (3): 199-210.

[79] Li, D., Zhu, H., Liu, K., Liu, X., Leggewie, G., Udvardi, M., Wang, D. (2002): Purple Acid Phosphatases of Arabidopsis thaliana. - J. Biol. Chem. 277: 27772-27781.

[80] Li, Y., Guohua, M., Fanjun, C., Jianhua, Z., Fusuo, Z. (2004): Rhizosphere Effect and Root Growth of two Maize (Zea mays L.) Genotypes with Contrasting P Efficiency at Low P Availability. - Plant Sci. 167: 217-223.

[81] Liu, J., Xie, J., Chu, Y., Sun, C., Chen, C., Wang, Q. (2008): Combined Effect of Cypermethrin and Copper on Catalase Activity in Soil. - J. Soils Sed. 8: 327-332.

[82] Madejon, E., Moreno, F., Murillo, J.M., Pelagrin, F. (2007): Soil Biochemical Response to Long-term Conservation Tillage under Semiarid Mediterranean Conditions. - Soil Tillage Res. 94:346-352.

[83] Magalhaes, P.O., Ferraz, A., Milagres, A.F.M. (2006): Enzymatic Properties of two $\beta$ glucosidases from Ceriporiopsis subvermispora Produced in Biopulping Conditions. - J. Appl. Microbiol. 101: 480-486.

[84] Malkomes, H. P. (1997): Applications of Ecotoxicity Tests to Assess side Effects of Pesticides in Soils. - In: Tarradellas, J., Bitton, G., Rossel, Rossel, D. (eds.) Soil Ecotoxicology, Lewis Publishers, Boca Raton, FL.

[85] Makoi, J., Ndakidemi, P. (2008): Selected Soil Enzymes: Examples of their Potential Roles in the Ecosystem. - African Journal of Biotechnology 7:181-91.

[86] Martinez, C.E., Tabatabai, M.A. (1997): Decomposition of Biotechnology By-products in Soils. - J Environ Qual. 26:625-632.

[87] Martinez-Salgado, M.M., Gutiérrez-Romero, V., Jannsens, M., Ortega-Blu, R. (2010): Biological Soil Quality Indicators: A Review. - In: Mendez-Vilas, A. (ed.) Current Research, Technology and Education Topics in Applied Microbiology and Microbial Biotechnology. (C) Formatex.

[88] McCarthy, G.W., Siddaramappa, R., Reight, R.J., Coddling, E.E., Gao, G. (1994): Evaluation of Coal Combustion By-products as Soil Liming Materials: Their Influence on Soil pH and Enzyme Activities. - Biol. Fert. Soils 17: 167-172.

[89] McGill, W.B., Colle, C.V. (1981): Comparative Aspects of Cycling of Organic C, N, S and P through Soil Organic Matter. - Geoderma, 26: 267-286.

[90] Megharaj, M., Boul, H.L., Thiele, J.H. (1999): Effects of DDT and its Metabolites on Soil Algae and Enzymatic Activity. - Biol. Fertil. Soils 29, 130-134.

[91] Menon, P., Gopal, M., Parsad, R. (2005): Effects of Chlorpyrifos and Quinalphos on Dehydrogenase Activities and Reduction of Fe3p in the Soils of two Semiarid Fields of Tropical India. - Agric. Ecosyst. Environ. 108: 73-83.

[92] Miller, S.S., Liu, J., Allan, D.L., Menzhuber, C.J., Fedorova, M., Vance, C.P. (2001): Molecular Control of Acid Phosphatase Secretion into the Rhizosphere of Proteoid Roots from Phosphorous Stressed White Lupin. - Plant Physiol. 127: 594-606.

[93] Mina, B. L., Saha, S., Kumar, N., Srivastva, A. K., Gupta, H. S. (2008): Changes in Soil Nutrient Content and Enzymatic Activity under Conventional and Zero-Tillage Practices in an Indian Sandy Clay Loam Soil. - Nutr Cycl Agroecosyst. 82:273-281.

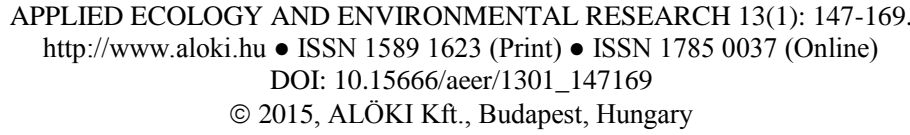


[94] Mobley, H.L.T., Hausinger, R.P. (1989): Microbial Urease: Significance, Regulation and Molecular Characterization. - Microbiol Rev. 53:85-108.

[95] Monkiedje, A., Ilori, M. O., Spiteller, M. (2002): Soil Quality Changes Resulting from the Application of the Fungicides Mefenoxam and Metalaxyl to a Sandy Loam Soil. - Soil Biol. Biochem. 34: 1939-1948.

[96] Nannipieri, P., Bollag, J.M. (1991): Use of Enzymes to Detoxify Pesticide Contaminated Soils and Waters. - J. Environ. Qual. 20: 510-517.

[97] Nannipieri, P. (1994): The Potential use of Soil Enzymes as Indicators of Productivity, Sustainability and Pollution. - In Pankhurst, C. E., Doube, B.M., Gupta, V.V.S.R., Grace, P. R. (eds.) Soil Biota: Management in Sustainable Farming Systems, CSIRO, East Melbourne.

[98] Ndakidemi, P.A. (2006): Manipulating Legume/Cereal Mixtures to Optimize the Above and Belowground Interactions in the Traditional African Cropping Systems. - Afr. J. Biotechnol. 5 (25): 2526-2533.

[99] Ndiaye, E.L., Sandeno, J.M., McGrath, D., Dick, R.P. (2000): Integrative Biological Indicators for Detecting Change in Soil Quality. - Am J Altern Agric. 15:26-36.

[100] Nicholls, R.G., Roy, A.R. (1971): Arylsulfatase. - In: Boyer, P.D. (ed.) The Enzymes, Vol. 5, $3^{\text {rd }}$ edn., Academic Press, New York.

[101] Nutt, A. (2006): Hydrolytic and Oxidative Mechanisms involved in Cellulose Degradation. - Digital Comprehensive Summaries of Uppsala Dissertations from the Faculty of Science and Technology 185.

[102] Okamota, K., Nakano, H., Yatake, H., Kiso, T., Kitahata, S. (2000): Purification and some Properties of $\beta$-glucosidase from Fusobacterium johnsonae. - Biosci. Biotechnol. Biochem. 64(2): 333-340.

[103] Perrucci, P., Scarponi, L. (1994): Effects of the Herbicide Imazethapyr on Soil Microbial Biomass and Various Soil Enzyme Activities. - Biol Fertil Soils 17:237-240.

[104] Pettit, N.M., Smith, A.R.J., Freedman, R.B., Burns, R.G. (1976): Soil Urease: Activity, Stability and Kinetic Properties. - Soil Biol Biochem. 8:479-484.

[105] Pierce, F.J., Larson, W.E. (1993): Developing Criteria to Evaluate Sustainable Land Management. - In: Kimble, J.M. (ed.) Proceeding of the VIII International Soil Management Workshop Utilization of Soil Survey Information for Sustainable Land use Sacramento, CA.

[106] Pitchel, J.R., Hayes, J.M. (1990): Influence of Fly Ash on Soil Microbial Activity and Populations. - J. Environ. Qual. 19: 593-597.

[107] Polacco, J.C. (1977): Is Nickel a Universal Component of Plant Ureases? - Plant Sci Lett. 10:249-255.

[108] Pragya, T., Misra, B.N., Sangwan, N.S. (2013): $\beta$-Glucosidases from the Fungus Trichoderma: An Efficient Cellulase Machinery in Biotechnological Applications. -BioMed Research International, Hindawi Publishing Corporation.

[109] Quiquampoix, H., Mousain, D. (2005): Enzymatic Hydrolysis of Organic Phosphorus. In: Turner, B.L., Frossard, E., Baldwin, D.S. (eds.) Organic Phosphorus in the Environment, Wallingford, UK7 CAB International.

[110] Rai, J.P.N. (1992): Effects of Long-term 2,4-D Application on Microbial Populations and Biochemical Processes in Cultivated Soil. - Biology and Fertility of Soils, 13: 187-1 91.

[111] Rajashekhararao, B.K., Siddaramappa, R.R. (2008): Evaluation of Soil Quality Parameters in a Tropical Paddy Soil Amended with Rice Residues and Tree Litters. European Journal of Soil Biology 44: 334-340.

[112] Reid, T.W., Wilson, I.B. (1971): E. Coli Alkaline Phosphatase. In: Boyer, P.D., (ed.) The Enzymes, Vol. 4, New York, USA7 Academic Press.

[113] Sadhu, S., Maiti, T. K. (2013): Cellulase Production by Bacteria: A Review. - British Microbiology Research Journal 3 (3): 235-258. 
[114] Saha, S., Mina, B. L., Gopinath, K. Kundu, A.S., Gupta, H. S. (2008): Organic Amendments Affect Biochemical Properties of a Subtemperate Soil of the Indian Himalayas. - Nutr Cycl Agroecosyst. 80:233-242.

[115] Sarathchandra, S.U., Perrott, K.W. (1981): Determination of Phosphatase and Arylsulphatase Activity in Soils. - Soil Biol. Biochem. 13: 543-545.

[116] Sardans, J., Peñuelas, J., Ogaya, R. (2005): Drought Decreases Soil Enzyme Activity in a Mediterranean Quercus ilex L. Forest. - Soil Biology and Biochemistry 37 (3): 455-461.

[117] Saviozzi, A., Levi-Minzi, R., Cardelli, R., Riffaldi, R. (2001): A Comparison of Soil Quality in Adjacent Cultivated, Forest and Native Grassland Soils. - Plant and Soil 233:251-9.

[118] Schaffer, A. (1993): Pesticide Effects on Enzyme Activities in the Soil Ecosystems. - In Bollag, J. M., Stotzk, Y. G. (eds.) Soil Biochemistry, Marcel Dekker, New York.

[119] Schaller, K. (2009): Soil Enzymes: Valuable Indicators of Soil Fertility and Environmental Impacts. Bulletin UASVM Horticulture, 66:2.

[120] Schinner, F., Öhlinger, R., Kandeler, E., Margesin, R. (1996): Methods in Soil Biology. Springer Verlag, Berlin.

[121] Schoen, S.R., Winterlin, W.L. (1987): The Effects of Various Soil Factors and Amendments on the Degradation of Pesticide Mixtures. - Journal of Environmental Science and Health 822: 347-377.

[122] Shukla, A. K. (1997): Effect of Herbicides Butachlor, Fluchloralin, 2, 4-d and Oxyfluorfen on Microbial Population and Enzyme Activities of Rice Field Soil. - Indian J. Ecol. 24: 189-192.

[123] Sicardi, M., Garcia-Prechac, F., Frioni, L. (2004): Soil Microbial Indicators Sensitive to Land use Conversion from Pastures to Commercial Eucalyptus grandis (Hill ex Maiden) Plantations in Uruguay. - Appl Soil Ecol., 27:125-133.

[124] Sinsabaugh, R.L., Linkins, A.E. (1989): Natural Disturbance and the Activity of Trichoderma viride Cellulase Complex. - Soil Biol Biochem. 21:835-839

[125] Sinsabaugh, R.L., Antibus, R.K., Linkins, A.E. (1991): An Enzymatic Approach to the Analysis of Microbial Activity during Plant Litter Decomposition. - Agric Ecosyst Environ. 34:43-54.

[126] Skladany, G.J., Metting, F.B. Jr. (1993): Bioremediation of Contaminated Soil. In: Metting, F.B., Jr (ed.) Soil Microbial Ecology, Marcel Dekker, New York.

[127] Spano, G., Rinaldi, A., Ugliano, M., Beneduce, L., Massa, S. (2005): A $\beta$ - glucosidase Producing Gene Isolated from Wine Lactobacillus plantarum is Regulated by Abiotic Stresses. - J. appl. Microbial. 98: 855-861.

[128] Speir, T.W., Ross, D.J. (1978): Soil Phosphatase and Sulphatase. - In: Burns, R.G. (ed.) Soil Enzymes. Academic, London, UK.

[129] Speir, T.W., Kettles, H.A., Parshotam, A., Searle, P.L., Vlaar, L.N.C. (1995): A Simple Kinetic Approach to Derive the Ecological Dose Value, $\mathrm{ED}_{50}$, for the Assessment of Cr (VI) Toxicity to Soil Biological Properties. - Soil Biology and Biochemistry 27:801-810.

[130] Sukumaran, R.K., Singhania, R.R., Pandey, A. (2005): Microbial Cellulases - Production, applications and challenges. Journal of Scientific and Industrial Research 64:832-844.

[131] Tabatabai, M.A. (1982): Soil Enzyme. -In: Page, A.L., Miller, E.M., Keeney, D.R. (eds.) Methods of Soil Analysis, Part 2. Chemical and Microbiological Properties, American Society of Agronomy, Madison, WI.

[132] Tabatabai, M.A. (1994): Soil Enzymes. -In: Weaver, R.W., Angel, J.S, Bottomley, P.S. (eds.) Methods of Soil Analysis, Part 2. Microbiological and Biochemical Properties, Soil Science Society of America Book Series no. 5, SSSA, Madison, WI:

[133] Tabatabai, M.A., Bremner, J.M. (1970): Arylsulphatase Activity of Soils. - SSSAP, 34: 225-229. 
[134] Tabatabai, M. A., Dick, W. A. (2002): Enzymes in Soil: Research and Developments in Measuring Activities. - In: Burns, R.G., Dick, R.P. (eds.) Enzymes in the Environment: Activity, Ecology and Applications, Marcel Dekker. Inc., USA.

[135] Tarafdar, J.C., Chhonkar, P.K. (1979): Phosphatase Production by Microorganisms Isolated from Diverse types of Soils. - Zentralbl Bakteriol Naturwiss. 134(2):119-24.

[136] Trasar-Cepeda, C., Leiros, M. C., Seoane, S., Gil-Sotres, F. (2000): Limitation of Soil Enzymes as Indicators of Soil Pollution. - Soil Biol. Biochem. 32, 1867-1875.

[137] Tu, C.M. (1993): Influence of Ten Herbicides on Activities of Microorganisms and Enzymes in Soils. - Bulletin of Environmental Contamination and Toxicology 51: 30-39.

[138] Turner, B., Haygarth, P. (2005): Phophatase Activity in Temperate Pasture Soils: Potential Regulation of Labile Organic Phosphorous Turnover by Phosphodiesterase Activity. - Science of the Total Environment. 344:37-6.

[139] Tyler, G. (1981): Heavy Metals in Soil: Biology and Biochemistry. - In: Paul, E.A., Ladd, and J.N. (eds.) Soil Biochem. Vol. 5, Dekker, New York.

[140] Veena, V., Poornima, P., Parvatham, R., Sivapriyadharsini, Kalaiselvi, K. (2011): Isolation and Characterization of $\beta$-glucosidase Producing Bacteria from Different Sources. - Afr. J. Biotechnol. 10(66): 14907-14912.

[141] Verdoucq, L., Czjzeck, M., Moriniere, J., Bevan, D.R., Esen, A. (2003): Mutational and Structural Analysis of Aglycone Specificity in Maize and Sorghum $\beta$-glucosidases. - J. Biological Chem. 278(27): 25055-25062.

[142] Versaw, W.K., Harrison, M.J. (2002): A Chloroplast Phosphate Transporter, PHT2; 1, Influences Allocation of Phosphate within the Plant and Phosphate-Starvation Responses. -Plant Cell 14: 1751-1766.

[143] Voets, J.P., Meerschman, P., Verstraete, W. (1974): Soil Microbiological and Biochemical Effects of Long-term Atrazine Applications. - Soil Biology and Biochemistry 6:149-152.

[144] Vong, P.C., Dedourge, O., Lasserre-Joulin, F., Guckert, A. (2003): Immobilized-S, Microbial Biomass-S and Soil Arylsulphatase Activity in the Rhizosphere Soil of Rape and Barley as Affected by Labile Substrate C and N Additions. - Soil Biol. Biochem. 35: 1651-1661.

[145] Walls-Thumma, D. (2000): Dehydrogenase Activity in Soil Bacteria. http://www.gardenguides.com/130633-dehydrogenase-activity-soil-bacteria.html.

[146] Wright, A.L., Reddy, K.R. (2001): Phosphorus Loading Effects on Extracellular Enzyme Activity in Everglades Wetland Soil. - SSSAJ, 65: 588-595.

[147] Yadav, R.S., Tarafdar, J.C. (2001): Influence of Organic and Inorganic Phosphorous Supply on the Maximum Secretion of Acid Phosphatase by Plants. - Biol. Fert. Soils 34: 140-143.

[148] Yang, Y.Z., Liu, S., Zheng, D., Feng, S. (2006): Effects of Cadium, Zinc and Lead on Soil Enzyme Activities. - Journal of Environmental Science 18 (6): 1135-41.

[149] Yang, L., Tianlai, L., Fusheng, L., Lemcoff, J.H., Cohen, S. (2008): Fertilization Regulates Soil Enzymatic Activity And Fertility Dynamics in a Cucumber Field. Scientia Horticulturae 116 (1): 21-26.

[150] Yun, S.I., Jeong, C.S., Chung, D.K., Choi, H.S. (2001): Purification and some Properties of a $\beta$-glucosidase from Trichoderma harzanium Type C-4. - Biosci. Biotechnol. Biochem. 65(9): 2028-2032.

[151] Zantua, M.I., Bremner, J.M. (1977): Stability of Urease in Soils. - Soil Biol Biochem. 9:135-140.

[152] Zhang, C., Yu, H., Bao, Y., An, L., Jin, F. (2001): Purification and Characterization of Ginsenoside- $\beta$-glucosidase from Ginseng. - Chem. Pharm. Bull. 49(7): 795-798.

[153] Zhang, Y., Wu, N., Zhou, G., Bao, W. (2005): Changes in Enzyme Activities of Spruce (Picea balfouriana) Forest Soil as Related to Burning in the Eastern Qinghai-Tibetan Plateau. - Applied Soil Ecology 30:215-225. 
[154] Zhang, Y., Wang, Y. (2006): Soil Enzyme Activities with Greenhouse Subsurface Irrigation Original Research Article. - Pedosphere 16 (4): 512-518. 